\title{
Analisis Kemampuan Pemecahan Masalah Matematika Siswa Melalui Pendekatan Matematika Realistik Berbantu Autograph Di SMP
}

\author{
Yenni Novita ${ }^{1}$, Hasratuddin², Firmansyah ${ }^{3}$ \\ 1,3Universitas Muslim Nusantara AI Washliyah, ${ }^{2}$ Universitas Negeri Medan, Indonesia \\ e-mail: yenninovita17@gmail.com
}

\begin{abstract}
Abstrak
Penelitian ini bertujuan untuk menganalisis peningkatan kemampuan pemecahan masalah matematika siswa melalui Pembelajaran Matematika Realistik (PMR) berbantu Autograph dan pembelajaran Eksposioiri pada siswa kelas VIII SMP AI-Washliya 8 Medan serta interaksi antara KAM terhadap kemampuan pemecahan masalah matematika siswa. Jenis penelitian ini adalah quasi eksperimen. Pemilihan sampel dilakukan secara purposive sampling, diperoleh sampel dua kelas yaitu VIII-1 dengan jumlah siswa 30 siswa dan kelas VIII-2 dengan jumlah siswa 30. Pengolahan data dilakukan dengan pengujian awal yaitu uji normalitas dan homogenitas, selanjutnya menguji hipotesis yang sesuai dengan rumusan masalah/hipotesis. Hasil penelitian menyatakan peningkatan kemampuan pemecahan masalah matematika siswa lebih baik melalui PMR daripada Ekspositori dan tidak terdapat interaksi antara pembelajarn kemampuan awal matematika siswa (tinggi, sedang, rendah) terhadap kemampuan pemecahan masalah matematika siswa SMP.
\end{abstract}

Kata Kunci: Pemecahan Matematis; Pendekatan Matematika Realistik; Autograph

\begin{abstract}
This study aims to analyze the improvement of students 'mathematical problem solving abilities through Realistic Mathematics Learning (PMR) assisted by Autograph and Expository learning in class VIII of Al-Washliya 8 Medan Middle School and the interaction between KAM on students' mathematical problem solving abilities. This type of research is a quasi-experimental. The sample selection is done by purposive sampling, obtained a sample of two classes namely VIII-1 with the number of students 30 students and class VIII-2 with the number of students 30. Data processing is done by preliminary testing of normality and homogeneity tests, then testing the hypothesis in accordance with the formulation of the problem / hypothesis. The results of the study stated that the improvement of students' mathematical problem solving skills was better through PMR than Expository and there was no interaction between students' early mathematics learning abilities (high, medium, low) on students' mathematical problem solving abilities.
\end{abstract}

Keywords: Problem solving ability; Realistic Mathematics Education; Autograph

\section{Pendahuluan}

Aktivitas kehidupan manusia sehari-hari hampir tidak pernah terlepas dari kegiatan belajar, baik ketika seseorang melaksanakan aktivitas, maupun di dalam suatu kelompok tertentu. Tidak ada ruang dan waktu dimana manusia dapat melepaskan dirinya dari kegiatan belajar, dan itu berarti pula bahwa belajar tidak pernah dibatasi usia, tempat maupun waktu, karena perubahan yang menuntut terjadinya aktifitas belajar (Winataputra, 2014). Dalam setiap kehidupan, manusia pasti akan mendapatkan sebuah permasalahan dan manusia akan mempunyai kemampuan yang berbeda untuk menyelesaikan sebuah permasalahan.

Begitu pula dalam pembelajaran matematika, kemampuan pemecahan masalah sangat terkait dengan kemampuan peserta didik dalam membaca dan memahami bahasa soal cerita, menyajikan dalam model matematika, merencanakan perhitungan dari model matematika, serta menyelesaikan perhitungan dari soal-soal yang tidak rutin. Pencapaian kemampuan pemecahan matematika memerlukan komunikasi matematika yang baik, dengan adanya interaksi yang seimbang antar sesama peserta didik, atau pun antara peserta didik dengan guru (Anisa, 2014).

Oleh karena itu, peserta didik dituntut untuk dapat memahami sebuah permasalahan sehingga peserta didik bisa memiliki kemampuan pemecahan masalah yang tepat. Hidayat, 
(2018) mengemukakan pemecahan masalah memuat empat langkah penyelesaiannya yaitu memahami masalah, merencanakan masalah, menyelesaikan masalah sesuai rencana dan melakukan pengecekan kembali terhadap semua langkah yang dikerjakan. Satu tahap ke tahap berikutnya dalam pemecahan masalah saling mendukung untuk menghasilkan pemecahan masalh yang termuat dalam soal. Siswa berperan dalam memahami setiap langkah dalam peme cahan masalah agar proses berpikir berjalan dengan baik. Dalam proses pembelajaran diperlukan suatu pola pikir yang menghasilkan solusi terhadap persoalan.

Namun faktanya banyak siswa yang tidak suka dengan matematika. Kurang sukanya siswa terhadap matematika jika dilihat dari individu siswa itu sendiri dapat disebabkan karena banyak faktor seperti kecerdasan, minat, cita-cita hingga latar belakang keluarga dan lingkungan dimana siswa lebih banyak menghabiskan waktunya di luar dari pada di sekolah. Sedangkan jika dilihat dari guru yang mengajarkan matematika, ketidak sukaan siswa terhadap matematika bisa dikarenakan gaya guru mengajar yang kurang menarik, metode mengajar guru yang monoton hingga pada pribadi guru yang kurang menyentuh hati siswa. Penelitian yang dilakukan oleh Manurung (2017) dan Simanjuntak (2017) juga mengemukakan dalam proses pembelajaran di dalam kelas, siswa juga belum terlibat secara aktif, banyak siswa yang sering mengantuk saat pembelajaran, tidak mau mengerjakan tugas yang diberikan, malas mencatat, suka melamun dan kurangnya intensitas bertanya siswa serta berbagai aktivitas lain yang menunjukkan bahwa motivasi, kemampuan berpikir kritis siswa dalam belajar matematika masih rendah khususnya pada pembelajaran matematika trigonometri.

Dari hasil survey dari penelitian Batubara (2017) berupa pemberian tes diagnosis kepada siswa SMA Free Methodist 2 menunjukkan bahwa 83,33\% dari jumlah siswa kesulitan menggambarkan kurva dari sebuah integral, dan $10 \%$ dari jumlah siswa tidak paham sama sekali dengan permasalahan yang ada dalam soal. Kurangnya pemahaman konsep siswa tersebut dapat dilihat dari contoh soal dalam menentukan integral-integral tak tentu dan integral tentu, menghitung integral Riemann dan menggambarkan grafiknya, menentukan luas daerah di bawah sebuah kurva dengan batas a dan b, serta menentukan luas daerah di bawah beberapa kurva.

Peningkatan kemampuan pemecahan masalah diperlukan juga dukungan dari guru untuk menggunakan pembelajaran secara realistik agar peserta didik merasa berada pada permasalahan yang nyata. Pembelajaran secara realistik merupakan pembelajaran yang berkonteks pada dunia nyata serta pembelajaran yang membebaskan peserta didik untuk merancang cara untuk memecahkan masalah yang dihadapi. Pembelajaran PMR sangat relevan untuk meningkatkan kemampuan pemecahan masalah, aktifitas serta keyakinan siswa Langkah-langkah pembelajaran model PMR sejalan dengan langkah tahap pemecahan masalah yang diusulkan oleh Polya, dijelaskan oleh Jurnal IImiah Pendidikan Dasar 26 Treffers dan Goffree dalam Armanto (2002: 24) langkah-langkah model PMR, yakni memahami masalah kontekstual yang realistik, 2) Menjelaskan masalah kontekstual yang realistik, 3) Menyelesaikan masalah kontekstual yang realistik, 4) Membandingkan dan mendiskusikan jawaban kontekstual yang realistik, 5) Menyimpulkan.

Selain model pembelajaran, dibutuhkan juga media pembelajaran. Media pembelajaran merupakan alat yang dapat digunakan sebagai perantara penyampaian pesan sehingga dapat langsung merangsang pemikiran peserta didik serta dapat meningkatkan minat belajar peserta didik. Media pembelajaran yang dipilih juga harus mengikuti perkembangn zaman salah satunya autograph. Menurut Hasibuan (2016), salah satu alat bantu yang efektif dan efisien dalam pemanfaatan komputer dalam menunjang kualitas pembelajaran adalah dengan menggunakan autograph. Menurutnya aplikasi autograph adalah aplikasi yang mempelajari tentang dua dimensi, tiga dimensi, statistik, transformasi, geometri, persamaan, koordinat, differensial, grafik, aljabar.

Menurut Ghozi1 \& Hilmansyah (2018) bahwa aplikasi autograph memberikan kontribusi dalam meningkatkan motivasi mahasiswa dalam belajar matematika. Selanjutnya, Ghozi1 \& Hilmansyah mengatakan bahwa autograph ini sangat bagus dalam visualisasi geometri, karna memiliki kemampuan grafik 2D dan 3D untuk topik-topik seperti 
transformasi, kerucut bagian, vektor, kemiringan, aplikasi integral danturunan. Pengguna dapat mengamati bagaimana fungsi, grafik, persamaan, dan perhitungan. Pembelajaran dengan menggunakan aplikasi autograph lebih efektif jika dibandingkan dengan pembelajaran konvensial.

Hal ini sejalan dengan hasil penelitian yang dilakukan oleh Buchori (2010) bahwa pembelajaran menggunakan autograph lebih efektif dibandingkan dengan pembelajaran konvensional. Temuan Manurung (2017) menyebutkan bahwa aktivitas kelompok siswa yang memperoleh pembelajaran melalui penerapan model CPS dengan menggunakan Autograph lebih baik/lebih aktif daripada aktivitas kelompok siswa yang memperoleh pembelajaran hanya melalui penerapan model CPS saja. Selain itu, Simanjuntak (2017) juga menegaskan penggunaan tekhnologi contohnya software matematika seperti Autograph sangat dibutuhkan dalam pembelajaran matematika untuk meningkatkan mutu pendidik, menciptakan suasana pembelajaran yang menarik minat siswa untuk mempelajari matematika. Temuan Batubara (2017) juga menegaskan bahwa peningkatan kemampuan pemahaman konsep matematik siswa yang diajarkan melalui pembelajaran berbasis masalah berbantuan autograph lebih tinggi dari pada yang diajarkan melalui pembelajaran berbasis masalah berbantuan geogebra.

Berdasarkan uraian tersebut, tujuan penelitian ini adalah untuk menganalisis pembelajaran matematika dengan menggunakan aplikasi autograph. Pada penelitian ini akan menganalisis kemampuan pemecahan masalam matematika melalui pendekatan matematika realistik berbantu autograp serta interaksi antara indikator kemapuan pemecahan masalah matematika.

\section{Metode}

Penelitian ini difokuskan terhadap kemapuan pemecahan masalah siswa melalui pendekatan matematika realistik berbantu ICT yang dilaksanakan di SMP AI-Washliyah 8 Medan pada tahun ajaran 2018/2019 semester genap. Penelitian ini dilakukan sebanyak 5 kali pertemuan atau 10 jam pelajaran (10 x 40 menit) pada masing masing kelas.

Populasi penelitian ini adalah seluruh siswa kelas VIII SMP AI-Washliya 8 Medan. Pemilihan sampel dilakukan dengan cara purposive sampling. Berdasarkan teknik pengambilan sampel tersebut diperoleh sampel sebanyak dua kelas yaitu kelas VIII-1 berjumlah 30 siswa dan VIII-2 yang juga berjumlah 30 siswa. Kelas VIII-1 dipilih sebagai eksperimen dengan pendekatan PMR dan Kelas VIII-2 dipilik sebagai kelas kontrol dengan pendekatan ekspositori.

Dengan rancangan yang digunakan dalam penelitian ini adalah (1) Tahap penyusunan perangkat pembelajaran berupa: RPP, LKS, dan instrumen penelitian berupa lembar tes kemampuan representasi matematika (2) Tahap uji coba yaitu tes kemampuan pemecahan masalah matematika (3) Tahap pelaksanaan eksperimen. Teknik pengumpulan data dalam penelitian ini menggunaka satu instrumen, yaitu tes kemampuan representasi matematis. Kriteria pengelompokkan berdasarkan rerata dan simpangan baku disajikan dalam Tabel 1 berikut ini :

Tabel 1. Kriteria Pengelompokan Kemampuan Siswa Berdasarkan KAM

\begin{tabular}{cc}
\hline Kemampuan & Kriteria \\
\hline Tinggi & $X \geq \bar{X}+S D$ \\
Sedang & $\bar{X}+S D<\mathrm{X}<\bar{X}-S D$ \\
Rendah & $\mathrm{X} \leq \bar{X}-S D$ \\
\hline
\end{tabular}

Keterangan $: \bar{X}$ adalah nilai rata-rata KAM

$S D$ adalah simpangan baku nilai KAM

Tes kemampuan pemecahan masalah matematika siswa disusun dalam bentuk tes uraian berdasarkan kriteria kemampuan pemecahan masalah dan materi yang dipelajari siswa. Pada tes juga dilakukan uji validitas dan reliabilitas serta daya pembeda. Pengolahan data dilakukan dengan pengujian awal yaitu uji normalitas dan 
homogenitas, selanjutnya menguji hipotesis yang sesuai dengan rumusan masalah/hipotesis. Perhitungan statistik menggunakan bantuan program komputer SPSS 20 dengan uji hipotesis ANOVA satu.

\section{Hasil dan Pembahasan}

\section{Hasil Penelitian}

Hasil pengelolahan data tes kemapuan awal matematika (KAM) yang sudah dilakukan, diketahui dibagi menjadi tiga kelompok yaitu tinggi, sedang dan rendah. Dari tabel 2 juga diketahui bahwa kelas VIII - 1 memperoleh nilai minimum 40,00 dan nilai maximum 66,67 . Untuk kelas VIII-2 memperoleh nilai minimum 60,00 dan nilai maximum 73,33 atau dapat dilihat melalui statistik deskriptif, sebagai berikut.

Tabel 2. Descriptive Statistics Kemampuan Awal Matematika

\begin{tabular}{lcccc}
\hline & N & Min & Max & Mean \\
\hline KAM kelas VIII-1 & 30 & 40.00 & 66.67 & 54,89 \\
KAM kelas VIII-2 & 30 & 60.00 & 73.33 & 65.33 \\
\hline
\end{tabular}

Dengan demikian, kesimpulan yang sama diketahui bahwa kemampuan awal matematika kelas VIII - 2 lebih baik dibandingkan dengan kelas VIII - 1. Karena sudah diketahui kemampuan awal, maka di tentukan kelas yang akan diberi perlakuan PMR berbantu autograp dan kelas yang akan diberi pembelajaran ekspositori mengaju oleh nilai rata-rata yang didapat seperti tabel berikut

Tabel 3. Penentuan Kelas Penelitian

\begin{tabular}{cccccc}
\hline No & $\begin{array}{c}\text { Kelas } \\
\text { Penelitian }\end{array}$ & Kemampuan & $\begin{array}{c}\text { Nilai Rata- } \\
\text { Rata }\end{array}$ & Kategori & Kesimpulan \\
\hline 1 & VIII-1 & KAM & 60,00 & Kurang & $\begin{array}{c}\text { Kelas PMR berbantu } \\
\text { Autograph } \\
2\end{array}$ \\
VIII-2 & KAM & 65,33 & Cukup & Kelas ekspositori \\
\hline
\end{tabular}

Dari Tabel.3, diketahui bahwa kelas yang membutuhkan perlakuan khusus adalah kelas VIII - 1, hal ini disebabkan masih berada di kategori kurang pada kemampuan awal matematika dalam menyelesaikan luas dan keliling lingkaran hanya pada kategori cukup maka akan diberikan perlakuan PMR berbantuan media autograph, sedangkan kelas VIII - 2 diberikan perlakuan ekspositrori tanpa bantuan autograph.

Setelah di lakukan penerapan kepada kelas VIII - 1 dengan menggunakan Pendekatan Matematika Realistik (PMR) dengan bantuan media autograph. Kemampuan pemecahan masalah, kelas eksperimen memperoleh hasil yang memuaskan, karena peserta didik dapat mengikuti pembelajaran PMR dengan bantuan media autograph, pembelajaran PMR mampu memberikan kesempatan peserta didik, mengikuti langkah pembalajaran sesuai dengan indikator kemampuan pemecahan masalah. Dalam hal ini diketahui bahwa nilai ninimumkelas eksperimen73,33 dan nilai maximum 93,33. Dengan demikian, dapat diketahui pendekatan pembelajaran dibantu dengan autograph, mampu memudahkan peserta didik mampu menyelesaikan setiap masalah yang diberikan. Penjelasan selanjutnya dapat diketahui melalui Tabel 4. Berikut.

Tabel 4. Descriptive Statistics Kemampuan Pemecahan Masalah Kelas Eksperimen

\begin{tabular}{ccccccc}
\hline & N & Min & Max & Mean & Std. Deviation & Variance \\
\hline $\begin{array}{c}\text { Nilai Kemampuan } \\
\text { Pemecahan Masalah }\end{array}$ & 30 & 73,33 & 93,33 & 84.8897 & 5.23260 & 27.380 \\
\hline
\end{tabular}

Oleh karena itu, kelas eksperimen memberikan kesempatan besar kepada peserta didik dalam menyelesaikan soal uraian yang diberikan oleh guru. Sama halnya dengan kelas 
eksperimen, kelas kontrol juga diberikan perlakuan ekspositori tanpa media untuk mengetahui kemampuan pemecahan masalah, diketahui dengan jelas kemampuan pemecahan masalah peserta didik dalam mengikuti pembelajaran ekspositori, memberikan peserta didik keragaman dalam memperoleh kemampuannya dalam menyelesaikan setiap soal.untuk hasil hasil kemapuan pemecahan masalah matematika kelas ekspositori dapat dilihat pada Tabel. 5:

Tabel 5. Descriptive Statistics Kemampuan Pemecahan Masalah kelas Ekspositori

\begin{tabular}{ccccccc}
\hline & N & Min & Max & Mean & Std. Deviation & Variance \\
\hline $\begin{array}{c}\text { Nilai Kemampuan } \\
\text { Pemecahan Masalah }\end{array}$ & 30 & 60,00 & 86,67 & 75.1110 & 8.56581 & 73.373 \\
\hline
\end{tabular}

Pada Tabel.5 tampak nilai minimum yang diperoleh adalah 60,00 dan maxsimum yang diperoleh adalah 86,67 pada kelas ekspositori pada tes kemampuan pemecahan masa;ah matematika peserte didik. Dengan demikian, dapat diketahui pendekatan pembelajaran dibantu dengan autograph, mampu memudahkan peserta didik mampu menyelesaikan setiap masalah yang diberikan. Berikut ini hasil pengujian data normalitas pada kemampuan pemecahan masalah dapat dilihat pada Tabel 6 berikut.

Tabel 6. Pengujian Normalitas Data Kemampuan Pemecahan Masalah

\begin{tabular}{llcc}
\hline & & $\begin{array}{c}\text { Kemampuan } \\
\text { Pemecahan Masalah }\end{array}$ & $\begin{array}{c}\text { Kemampuan Awal } \\
\text { Matematika }\end{array}$ \\
\hline $\mathrm{N}$ & Mean & 60 & 60 \\
Normal Parameters & $\mathrm{a}, \mathrm{b}$ & 80.0003 & 60.1118 \\
& Std. Deviation & 8.59264 & 8.09469 \\
Most Extreme & Absolute & .200 & .211 \\
Differences & Positive & .135 & .126 \\
Test Statistic & Negative & -.200 & -.211 \\
Asymp. Sig. (2-tailed) & & .200 & .211 \\
\hline
\end{tabular}

Sesuai dengan Tabel 6, bahwa data kemampuan pemecahan masalah dan kemampuan awal pemecahan masalah dinyatakan berdistribusi normal, hal ini ditunjukkan dengan perolehan nilai Asymp. Sig. (2-tailed) masing-masing, untuk kemampuan pemecahan masalah, diketahui bahwa nilai Asymp. Sig. (2-tailed) adalah 0,100 maka dapat disimpulkan bahwa data yang telah dikumpulkan berdistribusi normal atau diambil dari populasi normal. Sama halnya dengan kemampuan awal pemecahan masalah, diketahui bahwa diketahui bahwa nilai Asymp. Sig. (2-tailed) adalah 0,073, maka dapat disimpulkan bahwa data yang telah dikumpulkan berdistribusi normal atau diambil dari populasi normal.

Uji homogenitas adalah pengujian mengenai sama tidaknya variansi-variansi dua buah distribusi atau lebih. Pengujian homogenitas data menggunakan uji Levene's dengan menggunakan IBM SPSS for windows dengan syarat terima sig $>0,05$. Berikut hasil yang diperoleh:

Tabel 7. Pengujian Homogenitas Kemampuan Pemecahan Masalah

\begin{tabular}{cccc}
\hline $\mathbf{F}$ & $\mathbf{d f 1}$ & $\mathbf{D f 2}$ & Sig \\
\hline 1.120 & 7 & 52 & .365 \\
\hline
\end{tabular}

Dari tabel 7, diketahui bahwa data homogen, hal ini dapat dijelaskan sebagai berikut: Pada hasil di tabel 7 untuk data kemampuan pemecahan masalah, bahwa nilai sig adalah 0,365 atau 0,365 > 0,05. Dengan demikian, data juga dinyatakan homogen. Dalam hal ini, pengujian telah dilakukan dengan menganalisis setiap hasil yang diperoleh dengan menggunakan uji General Linier Models melalui IBM SPSS 22 for windowws, hasil dari analisis tersebut adalah. 
Indonesian Journal of Educational Research and Review, Vol. 3 No. 2, Tahun 2020

P-ISSN: 2621-4792, E-ISSN: 2621-8984

Tabel 8. Pengujian Hipotesis Penelitian Pemecahan Masalah

\begin{tabular}{lccccc}
\hline \multicolumn{1}{c}{ Source } & $\begin{array}{c}\text { Type III Sum of } \\
\text { Squares }\end{array}$ & Df & Mean Square & F & Sig. \\
\hline Corrected Model & $1883.018^{\mathrm{a}}$ & 7 & 269.003 & 5.656 & .000 \\
Intercept & 189542.599 & 1 & 189542.599 & 3985.272 & .000 \\
Kemampuan_awal & 446.094 & 5 & 89.219 & 1.876 & .115 \\
kelas_penelitian & 1209.540 & 1 & 1209.540 & 25.431 & .000 \\
Error & 2473.160 & 52 & 47.561 & & \\
Total & 388359.378 & 60 & & & \\
Corrected Total & 4356.178 & 59 & & & \\
\hline
\end{tabular}

$\mathrm{R}$ Squared $=.432$ (Adjusted R Squared $=.356$ )

Hipoetesis penilitian ini adalah

$\mathrm{H}_{\mathrm{a}}: \mu \mathrm{X}_{1} \mathrm{O}_{1} \neq \mu \mathrm{X}_{2} \mathrm{O}_{2}$ artinya terdapat peningkatan kemampuan pemecahan masalah matematik siswa yang diajarkan dengan pendekatan matematika realistik berbantu autograph lebih baik dari pembelajaran biasa, dengan syarat diterima jika nilai sig < 0,000 atau Fhitung $>$ Ftabel

$\mathrm{H}_{\mathrm{o}}: \mu \mathrm{X}_{1} \mathrm{O}_{1}=\mu \mathrm{X}_{2} \mathrm{O}_{2}$ artinya tidak terdapat peningkatan kemampuan pemecahan masalah matematik siswa yang diajarkan dengan pendekatan matematika realistik berbantu autograph lebih baik dari pembelajaran biasa, dengan syarat diterima jika nilai sig > 0,000 atau Fhitung $<$ Ftabel

Dapat disimpulkan bahwa Ha diterima dalam penelitian ini yaitu terdapat peningkatan kemampuan pemecahan masalah matematik siswa yang diajarkan dengan pendekatan matematika realistik berbantu autograph lebih baik dari pembelajaran biasa. Hal ini juga ditunjukkan dengan perbedaan nilai gain dalam proses pembelajaran, berikut hasil yang diperoleh:

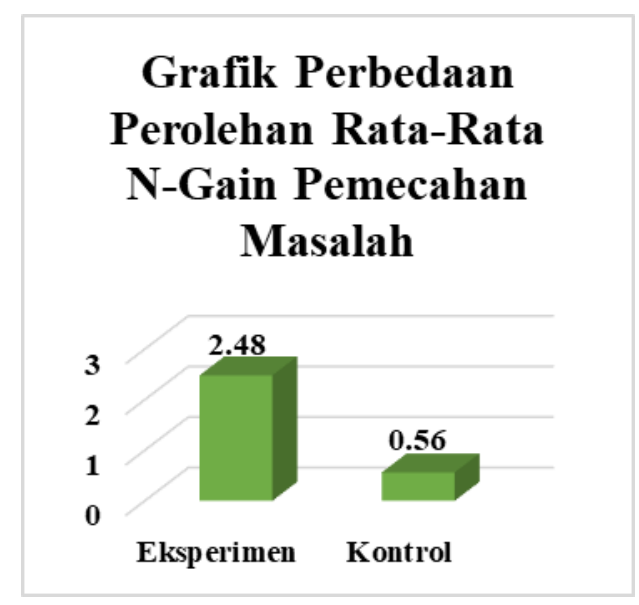

Gambar 1. Perbedaan Nilai Rata-Rata Gain Kemampuan Pemecahan Masalah

Dari Gambar 1, diketahui dengan jelas peningkatan terjadi sangat baik di kelas eksperimen dengan nilai rata-rata gain sebesar 2,48 dengan kategori tinggi, sedangkan kelas kontrol hanya memperoleh nilai rata-rata gain sebesar 0,56 dengan kategori sedang. Artinya dapat disimpulkan bahwa terdapat peningkatan kemampun pemecahan masalah matematika siswa melalui pendekatan matematika realistik berbantu ICT.

Dalam hal ini juga dapat dilihat perbandingan hasil yang diperoleh melalui penilaian persentase setiap indikator peemecahan masalah, yang dapat dijelaskan dalam Gambar berikut. 


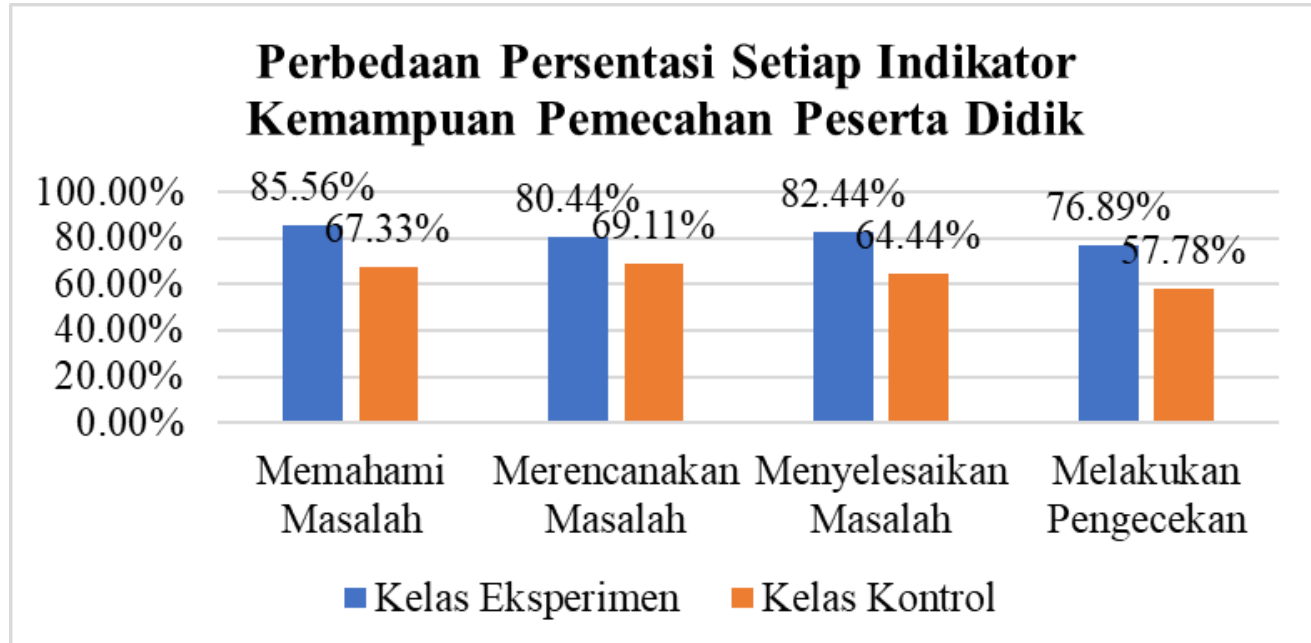

Gambar 2. Grafik Batang Perbedaan Presentasi Setiap Indikator Pemecahan Masalah Matematis Peserta Didik

Gambar 2, menjelaskan bahwa pada keempat indikator kemampuan pemecahan masalah terlihat lebih tinggi pencapaian kelas eksperiman dari pada kelas ekspositori sehingga dapat dinyatakan, pencapain kelas eksperimen lebih baik dari pada kelas ekspositori. Dan dapat diketahui bahwa interaksi merupakan kemampuan peserta didik berkomunikasi atau berhubungan dengan teman atau guru melalui PMR dengan bantuan media autograph, pembelajaran dengan PMR dengan bantuan autograph mampu memiliki perbedaan secara signifikan dalam berinteraksi atau memiliki umpan balik dalam menyelesaikan pembelajaran. Pengujian interaksi menggunakan uji General Linier Models. Hipotesis diterima atau ditolak jika :

$\mathrm{H}_{\mathrm{a}}: \mathrm{X}_{1} \times \mathrm{O}_{1} \neq 0$ atau terdapat interaksi antara pendekatan matematika realistik berbantu Autograph dengan pendekatan ekspositori terhaadap kemampuan pemecahan masalah matematika. Dengan menggunakan SPSS IBM 22 for windows, hipotesis alternatif diterima jika sig $<0,05$

$\mathrm{H}_{\mathrm{o}}: \mathrm{X}_{1} \times \mathrm{O}_{1}=0$ atau tidak terdapat interaksi antara pendekatan matematika realistik berbantu ICT dengan pendekatan ekspositori terhadap kemampuan pemecahan masalah matematika. Dengan menggunakan SPSS IBM 22 for windows, hipotesis nihil diterima jika sig $<0,05$. Dengan menggunakan SPSS IBM 22 for windows.

Tabel 9. Pengujian Hipotesis Interaksi

\begin{tabular}{lccccc}
\hline \multicolumn{1}{c}{ Source } & $\begin{array}{c}\text { Type III Sum of } \\
\text { Squares }\end{array}$ & Df & $\begin{array}{c}\text { Mean } \\
\text { Square }\end{array}$ & F & Sig. \\
\hline Corrected Model & $5202.332^{\mathrm{a}}$ & 5 & 1040.466 & 264.120 & .000 \\
Intercept & 319742.920 & 1 & 319742.920 & 81166.027 & .000 \\
Kelas & 4166.333 & 1 & 4166.333 & 1057.614 & .000 \\
Kemampuan & 950.640 & 2 & 475.320 & 120.659 & .000 \\
Kelas * Kemampuan & 85.359 & 2 & 42.679 & 2.834 & .180 \\
Error & 212.726 & 54 & 3.939 & & \\
Total & 325157.978 & 60 & & & \\
Corrected Total & 5415.058 & 59 & & & \\
\hline
\end{tabular}


Dari Tabel 9, diketahui bahwa Kelas Eksperimen* kelas ekspositori. dapat disimpulkan bahwa $\mathrm{H}_{0}$ diterima atau tidak terdapat interaksi antara pendekatan matematika realistik berbantu Autograph dengan pendekatan ekspositori terhaadap kemampuan pemecahan masalah matematika. Hal ini juga ditunjukkan dengan gambar grafik berikut:

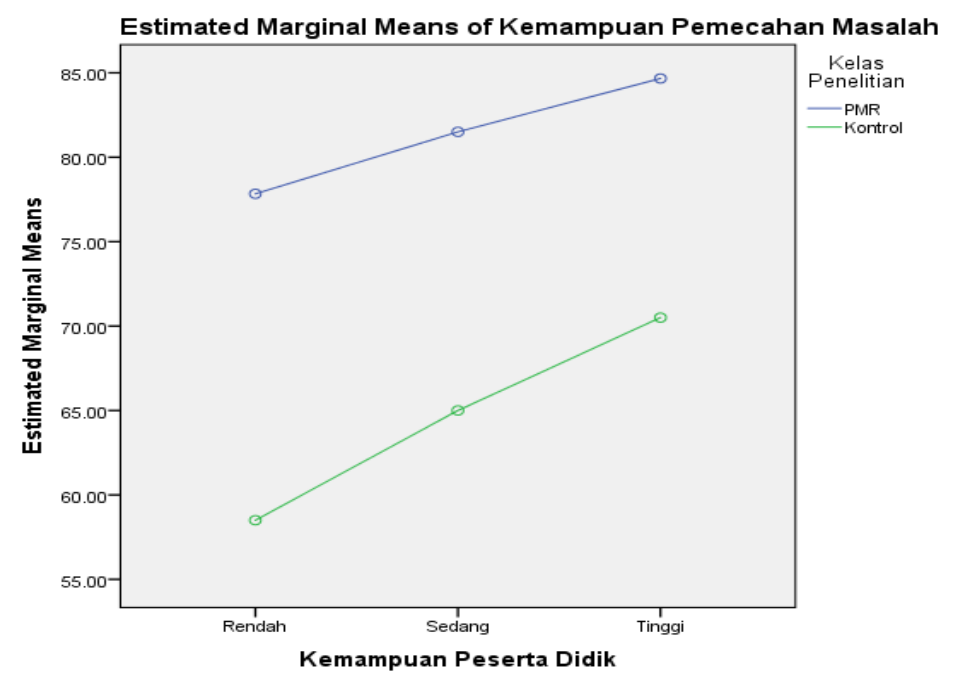

\section{Gambar 3. Grafik Interaksi Terhadap Kemampuan Pemecahan Masalah}

Dengan tidak adanya interaksi, maka diketahui dengan jelas bahwa dengan adanya pendekatan matematika realistik berbantu Autograph dengan kemampuan pemecahan masalah terhadap pendekatan ekspositori mampu memberikan pembelajaran yang lebih baik dalam memenuhi tujuan pembelajaran. Hal ini disebabkan bahwa hasil uji menegaskan secara statistik secara signifikan bahwa PMR dengan media Autograph mampu memberikan umpan balik dalam pembelajaran, sedangkan kelas kontrol hanya mampu memberikan kesempatan menenumukan hasil pembelajaran

\section{Pembahasan}

Berdasarkan analisis data yang telah dilakukan kemampuan pemecahan masalah yang untuk peserta didik yang diberi perlakuan pendekatan Realistik berbantu autograph lebih tinggi $18,23 \%$ dibandingkan peserta didik yang diberi perlakuan ekspositori dalam memahami masalah. Untuk indikator merencanakan masalah, perserta didik pada kelas eksperimen juga menunjukan 11,33\% lebih tinggi. Untuk indikator menyelesaikan masalah kelas ekspositori lebih rendah $20 \%$ dari pada kelas eksperimen. Serta pada indikator melakukan pengecekan kembali, kelas eksperimen lebih tinggi 19,11\%. Dengan demikian dapat dinyatakan bahwa dari keempat indikator kemampuan pemecahan masalah terletak selisih paling tinggi antar peserta didik dengan pendekatan Realistik berbantu Autograph dengan peserta didik pembelajaran ekspositori tedapat pada indicator menyelesaikan masalah. Dan berdasarkan analisi data perindikator maka dapat dikatakan tidak terdapat interaksi kemapuan pemecahan masalah antara pembelajar dengan pendekatan realistik berbantu Autograph terhadap pembelajaran ekspositori. Karena semua pencapaian indikator perserta didik dengan perlakuan pendekatan realistik berbantu Autograph lebih tinggi dibanding pencapaian indikator peserta idik dengan perlakuan pembelajaran ekspositori.

$\mathrm{Hal}$ ini sejalan dengan hasil penelitian yang dilakukan oleh Buchori (2010) bahwa pembelajaran menggunakan autograph lebih efektif dibandingkan dengan pembelajaran konvensional. Temuan Manurung (2017) menyebutkan bahwa aktivitas kelompok siswa yang memperoleh pembelajaran melalui penerapan model CPS dengan menggunakan Autograph lebih baik/lebih aktif daripada aktivitas kelompok siswa yang memperoleh pembelajaran hanya melalui penerapan model CPS saja. Selain itu, Simanjuntak (2017) juga menegaskan 
penggunaan tekhnologi contohnya software matematika seperti Autograph sangat dibutuhkan dalam pembelajaran matematika untuk meningkatkan mutu pendidik, menciptakan suasana pembelajaran yang menarik minat siswa untuk mempelajari matematika. Temuan Batubara (2017) juga menegaskan bahwa peningkatan kemampuan pemahaman konsep matematik siswa yang diajarkan melalui pembelajaran berbasis masalah berbantuan autograph lebih tinggi dari pada yang diajarkan melalui pembelajaran berbasis masalah berbantuan geogebra. Sehingga, berdasarkan analisis tersebut dapat disimpulkan bahwa untuk pemecahan masalah, penggunaan media autograph dapat sebagai alat perantara untuk menyampaikan materi sehingga waktu pembelajaran lebih efisien, kemudian tidak terdapat interaksi antara kemampuan pemecahan masalah peserta didik dengan pendekan realistik berbantu autograp terhadap kemampuan pemecahan masalah peserta didik pembelajaran ekspositori, dikarekan pembelajar menggunakan pendekatan realistik berbantu autograph lebih tinggi dalam pencapaian indikator kemapuan pemecahan masalah.

\section{Simpulan dan Rekomendasi}

Berdasarkan hipotesis dan jawaban hipotesis, maka dapat disimpulkan kemampuan pemecahan masalah matematik siswa yang diajarkan dengan pendekatan matematika realistik berbantu autograph lebih baik dari pembelajaran ekspositori. Selain untuk pemecahan masalah, penggunaan media autograph dapat sebagai alat perantara untuk menyampaikan materi sehingga waktu pembelajaran lebih efisien, kemudian tidak terdapat interaksi antara kemampuan pemecahan masalah peserta didik dengan pendekan realistik berbantu autograp terhadap kemampuan pemecahan masalah peserta didik pembelajaran ekspositori, dikarekan pembelajar menggunakan pendekatan realistik berbantu autograph lebih tinggi dalam pencapaian indikator kemapuan pemecahan masalah.

\section{Daftar Pustaka}

Anisa, W.N. 2014. Peningkatan Kemampuan Pemecahan Masalah Dan Komunikasi Matematik Melalui Pembelajaran Pendidikan Matematika Realistic Untuk Siswa Smp Negeri Di Kabupaten Garut. Jurnal pendidikan dan keguruan, 1(1).

Armanto, D. 2002. "Teaching Multiplication and Division Realistically in Indonesian Primary Schools: A Prototype of Local Instructional Theory". Doctoral Dissertation. Enschede: University of Twente.

Batubara, I. H. (2017). Peningkatan Kemampuan Pemahaman Konsep Matematis Melalui Model Pembelajaran Berbasis Masalah Berbantuan Autograph Dan Geogebra Di Sma Freemethodist Medan. Mes (Journal Of Mathematics Education And Science), 3(1), 47-54.

Buchori, Achmad. 2010. Keefektivan Penggunaan Autograph, Cabri 3d Dan Maple Sebagai Media Pembelajaran Matematika. AKSIOMA : Jurnal Matematika dan Pendidikan Matematika, 1(1).

Dharmayanti, A., \& Wijaya, A. (2018). Efektivitas Pendekatan pembelajaran Pendidikan Matematika Realistik Indonesia (PMRI) Ditinjau Dari Kemapuan Penalaran dan kemampuan Pemecahan Masalah Siswa SMP. Jurnal Pendidikan Matematika-S1, 7(4), 29-37

Ghozi1 \& Hilmansyah. 2018. Visualisasi Geometris Aplikasi Integral: Studi Penggunaan Software Autograph Dalam Pembelajaran Matematika Teknik. JNPM (Jurnal Nasional Pendidikan Matematika), 2 (1).

Hasibuan, Nailul Himmi. 2016. Pemanfaatan Autograph Sebagai Media Pembelajaran Matematika Dengan Menerapkan Model Pembelajaran Berbasis Masalah (PBM). Cahaya Pendidikan, 2(1).

Hasratuddin. (2018). Mengapa Harus Belajar Matematika cetakan kedua. Medan : Edira

Hidayat, W., \& Sariningsih, R. (2018). Kemampuan pemecahan masalah matematis dan adversity quotient siswa SMP melalui pembelajaran open ended. JNPM (Jurnal Nasional Pendidikan Matematika), 2(1), 109-118. 
Jeheman, A. A., Gunur, B., \& Jelatu, S. (2019). Pengaruh pendekatan Matematika Realistik terhadap pemahaman Konsep Matematika Siswa. Mosharafa : Jurnal Pendidikan Matematika, 8(2), 191-202

Kartikasari, R, Nurrahmah, a., \& Pujiati, A. (2019). Kemampuan Pemecahan Masalah Matematis Melalui Pendekatan Pendidikan matematika Realistik Indonesia (PMRI). Jurnal Pendidikan, 5(2)

Manurung, S. L. (2017). Peningkatan Kemampuan Berpikir Kritis Siswa Melalui Penerapan Model Pembelajaran Creative Problem Solving (Cps) Dengan Menggunakan Software Autograph. Jurnal Kebijakan Dan Pengembangan Pendidikan, 1(1), 1-8.

Matondang, K. (2016). Perbedaan Peningkatan Kemampuan Komunikasi dan Pemecahan Masalah Matematik Siswa Melalui Pembelajaran Berbasis Masalah Dengan Pembelajaran Matematika Realistik. Medan: Tesis PPs Unimed. Tidak diterbitkan.

Rahman, A. A. (2018). Pengembangan Perangkat Pembelajaran Berbasis pendekatan Realistik untuk Meningkatkan Kemampuan Pemecahan Masalah Matematis Siswa SMP N 3 Langsa. MAJU: Jurnal IImiah Pendidikan Matematika, 4(1).

Sinaga, M. A. (2018). Perbedaan Kemampuan Pemecahan Masalah Matematika Siswa Yang Menggunakan Pendekatan Pembelajaran Matematika Realistik Dan Pembelajaran Berbasis Masalah Pada Materi Sistem Persamaan Linier Tiga Variabel Kelas X Sma Negeri 1 Tanjung Morawa Ta 2017/2018(Doctoral Dissertation, Unimed).

Sipayung, E. S. (2017). Perbedaan Kemampuan Pemecahan Masalah Matematik Siswa Diajarkan Melalui Pembelajaran Matematika Realistik Dan Pembelajaran Berbasis Masalah Berbantuan Autograph Sma Negeri I Panombeian Panei T. A 2017/2018 (Doctoral Dissertation, Unimed).

Winataputra, U. S., Delfi, R., Pannen, P., \& Mustafa, D. (2014). Hakikat Belajar dan Pembelajaran. Hakikat Belajar dan Pembelajaran, 1-46

Simanjuntak, M. (2017). Model Pembelajaran Kooperatif Think-Talk-Write (Ttw) Dan Software Autograph Dalam Mempersiapkan Pendidik Matematika Menghadapi Masyarakat Ekonomi Asean (Mea). Jurnal Dinamika Pendidikan, 9(2), 71. Https://Doi.Org/10.33541/Jdp.V9i2.339 